\title{
Implementasi Program Maghrib Mengaji Kota Bandung
}

\author{
${ }^{1}$ Tri Asih Wismaningtyas
}

${ }^{1}$ Universitas Tidar, Indonesia; triasihwismaningtyas@untidar.ac.id

\begin{abstract}
The current modernization era and the development of electronic mass media has given birth to a shift in values, culture, and traditions of society, both in rural areas and especially in urban areas. The impact of this has given rise to very significant social changes in society, the impact of the good tradition of community groups at this time has been eroded by cultural acculturation and values that are at odds with the conditions and traditions of Indonesian society, including the culture of reciting after the evening prayer or regular prayers known as the evening recitation. The aim of this article is to focus on the implementation of Maghrib Mengaji. This research used a qualitative approach by literature study. The result of the research is Maghrib Mengaji is a part of the manifestation of Bandung Masagi, a religious education, national defense, culture and save the environment program. In the implementation, the Bandung City Government cannot conduct it alone. They need involve many community actors who could become a cooperative and interactive partnership. This research conclude that Maghrib Mengaji program was carried out well by professional and responsible networking actors. Further, this program recognized as a model for a pilot project for other regions in West Java Province.
\end{abstract}

Keywords: Public Policy, Program Implementation, Civil Society, Participation, Local Government.

\section{Pendahuluan}

Mengaji merupakan salah satu aktivitas ibadah yang sangat melekat dengan masyarakat muslim di Indonesia sejak mula berkembangnya Islam. Sejumlah rumah ibadah seperti surau, musala, langgar, masjid dan lain-lain senantiasa diramaikan dengan kegiatan mengaji, khususnya di waktu petang setelah shalat Asar maupun Maghrib. Bagi kaum muslim di Indonesia, mengaji tak ubahnya menjadi lembaga pendidikan keagamaan nonformal bagi semua anak didik (Ditjen Bimas Islam Kemenag, 2013). Namun kini seiring berjalannya waktu, arus modernisasi zaman dan perkembangan media massa elektronik telah melahirkan pergeseran nilai, kultur, dan tradisi masyarakat, baik di pedesaan dan khususnya di perkotaan. Dampak dari hal tersebut telah melahirkan perubahan sosial yang sangat signifikan di tengah masyarakat, imbasnya tradisi baik kelompok masyarakat pada saat ini telah tergerus oleh akulturasi budaya dan nilai-nilai yang berseberangan dengan kondisi dan tradisi masyarakat Indonesia, termasuk budaya mengaji setelah waktu shalat Maghrib atau biasa dikenal dengan Maghrib Mengaji.

Adanya perkembangan teknologi internet dan perubahan gaya hidup, kegiatan anakanak mulai mengalami pergeseran, aktifitas yang sarat dengan kegiatan religi dan kebersamaan sekarang digantikan dengan berbagai sibuk bermain gawai. Bahkan Rumah Sakit Jiwa (RSJ) Provinsi Jawa Barat (Jabar) merawat ratusan anak yang mengalami gangguan jiwa, akibat kecanduan gadget atau gawai (www.nasional.okezone.com, 2019). 
Sebuah kondisi yang sangat disayangkan, kegiatan aktifitas yang kurang bermanfaat ini menggantikan religi yang dulu banyak anak-anak rutin melaksanakannya, seperti kegiatan mengaji Al-Qur'an di waktu mendekati atau setelah sholat Maghrib. Musala dan masjid sekarang cenderung sepi dari ramainya anak-anak di waktu Maghrib. Kondisi ini juga sering dijumpai hampir di setiap musala dan masjid Kota Bandung saat-saat sekarang.

Hal tersebut akhirnya mendorong pemerintah, dalam hal ini Pemerintah Kota Bandung, mengeluarkan sebuah kebijakan "Program Maghrib Mengaji" bagi anak-anak di Kota Bandung, yang diselenggarakan di setiap masjid yang ada. Program ini merupakan langkah lanjutan dari Surat Keputusan Menteri Agama Republik Indonesia nomor 150 tahun 2013 tentang Pedoman Gerakan Maghrib Mengaji. Pada tahun 2016, Walikota Bandung, Dr. H. Ridwan Kamil, MUD. bersama Kakemenag Kota Bandung, Dr. H. Yusuf, M.Pd yang saat itu menjabat meluncurkan program Gerakan Maghrib Mengaji. Dalam mengimplementasikan programnya, pemerintah juga berupaya untuk mengajak seluruh komponen masyarakat, baik itu yang berasal dari ormas Islam, non-governmental organization (NGO), perguruan tinggi, para alim ulama, tokoh masyarakat, hingga para orang tua dalam mendukung budaya Maghrib Mengaji ini.

Dalam melihat kebijakan program Maghrib Mengaji ini, penulis mencoba mengaitkannya dengan "society-centered approach", sebuah pendekatan yang membahas struktur sosial dan tekanan sosial yang ada, berhubungan dengan kelas sosial atau kepentingan sosial. Hal ini dikarenakan struktur sosial dan tekanan sosial memiliki dampak yang cukup signifikan terhadap negara dan cenderung lebih fokus kepada mengklarifikasi bagaimana dan untuk apa sebetulnya negara meraih suatu kekuasaan dari masyarakat (Turner \& Hulme, 1997). Kemudian berlanjut kepada implementasi kebijakan sebagai salah satu tahapan penting dalam siklus kebijakan program Maghrib Mengaji ini. Birkland (2001) menjelaskan bahwa implementasi adalah kunci dari sebuah kebijakan. Dalam kaitannya dengan pengelolaan kepentingan publik menurut pandangan Shafritz \& Russell (2005) mengemukakan bahwa implementasi adalah proses mewujudkan program pemerintah; itu adalah proses total menerjemahkan mandat hukum, apakah perintah eksekutif pada patung yang diberlakukan menjadi arahan dan struktur program yang sesuai yang menyediakan layanan atau barang kreatif.

Kebijakan yang telah direkomendasikan bukan jaminan bahwa kebijakan tersebut pasti berhasil dalam implementasinya. Perhatian yang meningkat terhadap pelaksanaan kebijakan pemerintah berhubungan erat dengan tumbuhnya kesadaran bahwa fokus perhatian dari implementasi kebijakan adalah memahami apa yang secara nyata terjadi setelah suatu program tersebut dinyatakan resmi, agar memberikan dampak dan mencapai tujuan yang diinginkan (Santosa, 2012). Sehingga setelah sebuah paradigma "governance" masuk kedalam istilah public policy, kemudian muncul apa yang disebut dengan "The Conception of Governance and Policy Network: New Form of Policy Implementation", dimana pemerintah dalam mengimplementasikan suatu kebijakan itu dapat dilakukan melalui "otoritas informal" dari sejumlah jaringan yang berbeda dan fleksibel (Ball 2012). Maka dari itu, berikut ini adalah sebuah kerangka teoritis yang menggambarkan bagaimana implementasi kebijakan ini dapat berjalan (Honig 2006). 


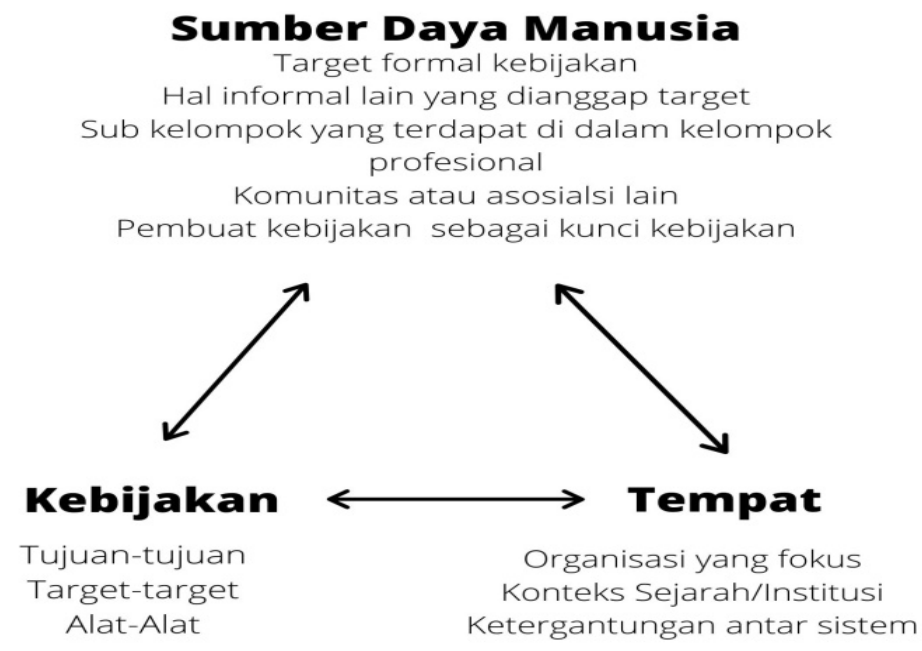

Sumber: Honig, 2006

Di era good governance ini, Pemerintah telah mentransformasikan hubungan antarpemerintah itu sendiri, dimana segala sesuatunya itu terkoneksi di dalam suatu jaringan yang meliputi interaksi antar lembaga pemerintahan dan organisasi masyarakat. Castells (1996) melihat bahwa pemerintah membutuhkan sebuah manajemen kolaborasi, dimana dalam menjalankan sebuah kebijakan itu dibutuhkan banyak aktor yang terlibat, agar masalah yang dihadapi itu akan lebih mudah untuk diselesaikan, karena sejatinya yang menjadi permasalahan publik itu sangat kompleks, tidak dapat diselesaikan oleh satu aktor saja yaitu pemerintah. Agen-agen publik dan kelompok masyarakat ini saling berhubungan dalam sebuah tujuan untuk saling menukar informasi, meningkatkatkan kapabilitas satu dengan yang lainnya, meluweskan interaksi pelayanan, dan memecahkan permasalahan kebijakan (Agranoff, 2007). Beberapa jaringan tersebut adalah seperti bangunan yang didasarkan pada bentuk hubungan yang interaktif dan kooperatif dalam rangka kesanggupan mereka untuk mensukseskan pelaksanaan suatu program kebijakan (Kilduff \& Tsai, 2003).

Setelah terbentuk jaringan ini, tidak lantas setelah terbentuknya mereka lalu ditinggalkan atau dibiarkan begitu saja, tetapi bagaimana aktor-aktor dalam jaringan ini mampu menjaga komitmen bersama (Agranoff et al, 2013). Oleh karena itu, pemerintah sebagai pengelola jaringan mampu memfasilitasi kebutuhan dan mempertimbangkan nilai yang dianut oleh parapelaksananya, karena itu adaptasi dan diskresi dalam implementasi seharusnya dilihat sebagai suatu yang dibutuhkan (Nakamura 1987).

Dalam rangka mendukung aktivitas dan memfasilitasi kebutuhan aktor-aktor jaringan ini, maka perlu dilakukan beberapa hal. Pertama, nampaknya pemerintah perlu mempertimbangkan kelayakan sisi finansial. Kendati menjadi hal yang paling diperdebatkan, namun hal ini adalah bentuk apresiasi terhadap kinerja yang telah dicapai oleh aktor-aktor tersebut. Sehingga kedepannya mereka mampu meningkatkan kualitas kerjanya (Gray, 1985). Kedua, pemerintah perlu meningkatkan kualifikasi keilmuan aktor-aktor ini, disebabkan ilmu pengetahuan yang berkembang ditambah dengan kemajuan teknologi yang semakin canggih. (Agranoff, 2007). Dan yang ketiga adalah dalam rangka memperluas diskursus jaringan 
kedalam sebuah teori baru yang berpotensial, yaitu dengan menciptakan sebuah nuansa baru yang bersifat kekeluargaan diantara pemerintah dan jaringan-jaringannya layaknya "governance of society" (Peters 2000), yang mana sesungguhnya segala aktivitas aktor-aktor network tersebut dengan sendirinya akan menambah value bagi mereka dan masyarakat secara lebih luas (Moore, 1995).

Sebetulnya nilai tambah bagi publik ini dapat dilihat dari perspektif partner kolaboratif secara individu. Pertama, berkaitan dengan bertambahnya pengetahuan dan kemampuan mereka melalui pekerjaan yang dilakukannya bersama yang lainnya. Kedua, aktor-aktor kolaborasi ini dapat belajar bagaimana mereka mampu bekerjasama antar individu dengan latar belakang berbeda beserta organisasi yang berbeda pula. Ketiga, dari hal tersebut mereka mampu meningkatkan kemampuan untuk mengelola dan bekerjasama di area yang menjadi tugas pemerintahan. Keempat, mereka mempunyai kesempatan satu sama lain untuk membangun suatu hubungan diluar tugasnya dan mampu memperoleh akses kedalamnya. Kelima, mereka merasa bahwa dengan terjalinnya suatu hubungan dalam network ini, mampu memperkuat motivasi mereka dalam melakukan pelayanan publik dan memberikan mereka kesempatan tambahan untuk dapat melakukan hal lain yang lebih positif terhadap publik yang lebih luas (Agranoff, 2007). Jadi, untuk mengetahui lebih jauh terkait Implementasi Kebijakan Program Maghrib Mengaji di Kota Bandung ini, penulis mencoba memetakannya kedalam sebuah tujuan penelitian, yaitu untuk menganalisis bagaimana Pemerintah Kota Bandung dengan jaringan-jaringannya mampu mengimplementasikan kebijakan Maghrib Mengaji.

\section{Metode Penelitian}

Penelitian ini menggunakan pendekatan kualitatif dengan jenis penelitiannya yaitu studi literatur. Dalam penelitian ini, peneliti hanya mendasarkan pada sejumlah literatur baik itu riset kepustakaan dan riset lapangan, yang sifatnya primer maupun sekunder. Selain itu juga peneliti tidak perlu untuk melakukan penelitian lapangan dan bertemu dengan informan. Dalam melakukan analisis data, peneliti menggunakan teknik systematic literature review, dimana peneliti melakukan proses identifikasi, penilaian, dan interpretasi sejumlah data yang berkaitan dengan tema penelitian yang telah ditentukan sebelumnya dalam rangka untuk memenuhi tujuan penelitian (Kitchenham \& Charters, 2007). Peneliti menggunakan konsep society-centered approach, network manager, tiga model dimensi implementasi kebijakan serta added values for pubic dengan network model dalam menganalisis fenomena implementasi program Maghrib Mengaji di Kota Bandung. Sumber data yang peneliti gunakan dalam mengembangkan penelitian ini diantaranya adalah sejumlah buku teks, artikel, jurnal, dan prosiding dengan skala nasional dan internasional serta laman website, berita elektronik, dokumen pemerintah, dan peraturan perundang-undangan.

\section{Hasil dan Pembahasan}

\section{Program Maghrib Mengaji}

Pemerintah Kota Bandung yang dipimpin langsung oleh Wali Kota Bandung secara resmi telah meluncurkan "Program Maghrib Mengaji" pada hari Jumat, 29 April 2016 yang lalu di Masjid Al-Ukhuwwah Kota Bandung (www.jabar.kemenag.go.id, 2016). Peresmian program ini dihadiri dan disaksikan langsung oleh aparatur pemerintah mulai dari Lurah, Camat dan jajaran organisasi perangkat daerah (OPD) se-kota Bandung, elemen masyarakat yang terdiri dari tim penggerak pemberdayaan dan per PKK, RW, DKM, LPM, MUI, Karang 
Taruna, Penyuluh Agama, Kelompok Informasi Masyarakat (KIM), beserta ribuan masyarakat lainnya yang berasal dari seluruh wilayah Kota Bandung.

Program Maghrib Mengaji ini sebetulnya adalah bagian pengejawantahan dari Bandung Masagi, yakni pendidikan agama, bela negara, budaya dan cinta lingkungan. Maghrib Mengaji sendiri adalah program Pemerintah Kota Bandung yang bertujuan untuk membangun generasi muda Kota Bandung menjadi Generasi Agamis. Harapannya, program Maghrib Mengaji ini dapat menjadi program untuk mempersiapkan pemimpin Indonesia masa depan yang memiliki karakter akhlakul-karimah, serta cerdas intelektual, sosial dan spiritual. Secara lebih khusus tujuan program Maghrib Mengaji ini adalah sebagai berikut:

1. Membentuk kepribadian berdasarkan Al-Qur'an dan mencegah kerusakan moral

2. Menumbuhkan ghirah (semangat) dan kecintaan terhadap kitab suci Al-Qur'an

3. Menumbuhkan gerakan membaca Al-Qur'an baik secara individu maupun bersama-sama (berjama'ah)

4. Memakmurkan Masjid atau Musala

5. Memberantas buta huruf Al-Qur'an

6. Tempat pembinaan, bimbingan, dan media kegiatan belajar-mengajar Al-Qur'an dan Sebagai wadah dan media untuk saling berdiskusi dan berkomunikasi, khususnya dalam bidang keagamaan

7. Membiasakan diri dengan kegiatan yang positif dan bermanfaat yang mengandung nilai ibadah

8. Meningkatkan kualitas hubungan kerjasama antara orang tua, masyarakat dengan unsur pendidikan dan pemerintah.

Dalam mengimplementasikan Maghrib Mengaji ini, Pemerintah Kota Bandung sendiri telah melibatkan beberapa pihak dalam mendukung program tersebut, sampai kemudian pemerintah telah mengantongi lebih dari 2000 relawan pengajar yang tersebar di lebih 2000 Masjid di setiap Rukun Warga (RW) yang telah dipasangi spanduk oleh Pemerintah Kota Bandung. Mereka para pengajar ini berasal dari unsur Universitas yang direpresentasikan oleh Mahasiswa dari Universitas Islam Negeri (UIN) SGD Bandung dan Universitas Islam Bandung (UNISBA), para penyuluh Agama Islam Kota Bandung, para Ustadz dan Kiayi, hingga pengurus Ikatan Remaja Mesjid DKM di Kota Bandung.

Menariknya, dalam rangka mensukseskan implementasi kebijakan ini, Pemerintah Kota Bandung sendiri telah menciptakan sebuah aplikasi pendukung yang bernama "Maghrib Mengaji". Aplikasi ini dimaksudkan untuk membagikan segala aktivitas mengaji di setiap masjid yang ada, baik itu berupa dokumentasi foto-foto, laporan kegiatan mengaji mereka, hingga info pengajian dan tabligh akbar yang diselenggarakan di seluruh Masjid Kota Bandung. Hal ini memungkinkan setiap warga dapat mengetahui lebih detail, aktivitas apa saja yang dilakukan anak-anak nya dalam program Maghrib Mengaji ini.

Dalam program tersebut, anak-anak tak hanya mengaji Al Quran atau Iqro saja, namun juga dibekali dengan pendidikan karakter lainnya. Diketahui bahwa dengan program Maghrib Mengaji ini diharapkan bukan sekedar mengajarkan baca Al-Quran saja, tapi juga pendidikan karakter bagi anak-anak. Mengajinya sekitar 70 persen, 30 persen sisanya minta para pengajar bukan hanya mengajar tadarus atau iqro, tetapi juga terdapat kegiatab ceramah. Seperti misalnya persoalan pendidikan antikorupsi, antinarkoba, pergaulan bebas dan lainnya. Dengan program Maghrib Mengaji ini, dapat menjadi sebuah tradisi posistif yang membuat 
anak-anak Kota Bandung kedepannya cerdas dalam memilih aktivitas yang jauh lebih bermanfaat untuk mereka. Jadi, Kota Bandung ini akan kokoh tidak hanya infrastrukutur secara fisik saja tetapi juga kokoh akhlaknya, yaitu dengan menyeimbangkan tiga kecerdasan manusia itu sendiri, yang terdiri dari kecerdasan Intellectual Question (IQ), Emotional Question (EQ), dan Spritual Question (SQ)." (Bandung.go.id. Diskominfo Kota Bandung, 2016).

\section{Analisa Pendekatan, Teori, dan Model}

Pertama, penelitian ini menggunakan Society-centered approach untuk melihat bagaimana program Maghrib Mengaji di Kota Bandung ini dapat diimplementasikan. Hal ini bisa dilihat dari dua faktor utama, yaitu struktur sosial dan adanya "tekanan sosial" masyarakat. Dilihat secara struktur sosial masyarakat Kota Bandung. Berdasarkan pada data Badan Pusat Statistik (BPS) Kota Bandung tahun 2010, jumlah penduduk kota ini sebanyak 2.470.802 jiwa, dimana telah tersebar ke 30 kecamatan yang di dalamnya terdapat 151 kelurahan. Dari masing-masing kelurahan terdapat Rukun Tangga (RT) secara keseluruhan berjumlah 9.677 dan untuk Rukun Warga secara keseluruhan berjumlah 1.560. Dalam perkembangannya, penduduk Kota Bandung berdasarkan proyeksi penduduk tahun 2019 sebanyak 2.507.888 jiwa yang terdiri atas 1.263.916 jiwa penduduk laki-laki dan 1.243.972 jiwa penduduk perempuan (BPS Kota Bandung, 2020).

Dari jumlah penduduk tersebut, kemudian berdasar pada data Badan yang sama tentang pembagian penduduk menurut wilayah dan agama yang dianut di Kota Bandung, didapati bahwa mayoritas penduduk di Kota Bandung didominasi oleh pemeluk agama Islam dengan jumlah penduduk sebanyak 2.195.994 jiwa. Agama yang dianut paling banyak kedua yaitu Kristen Protestan sebanyak 128.371 jiwa, disusul dengan penduduk beragama Katolik sebanyak 46.719 jiwa. Sedangkan untuk penduduk yang beragama Hindu sebanyak 2.146 jiwa dan yang beragama Buddha sebanyak 11.732 jiwa dan sisanya mereka yang beragama Konghuchu sebanyak 622 jiwa (BPS, 2010). Berdasarkan data di atas, agama Islam mendominasi di seluruh kecamatan di Kota Bandung. Kemudian dari mayoritas penduduk muslim Kota Bandung tersebut, ada sekitar 393.292 anak berusia 5-14 tahun yang menjadi sasaran dari program Maghrib Mengaji ini.

Melihat struktur sosial masyarakat Kota Bandung yang demikian, cukup jelas bagi penulis bahwa program Maghrib Mengaji ini begitu potensial untuk mengimplementasikannya. Hal ini disebabkan oleh faktor kedua, yaitu adanya tekanan masyarakat Kota Bandung sendiri. Ini dapat dilihat dari penterjemaahan Kota Bandung sebagai Bandung Masagi, yaitu pendidikan agama, bela negara, budaya dan cinta lingkungan. Ditempatkannya pendidikan agama ini sebagai unsur pertama telah membuat masyarakat Kota Bandung sejak dahulu hingga sekarang menjadi masyarakat yang santun dan religius. Oleh karena itu, Pemerintah Kota Bandung tidak menginginkan kultur baik tersebut itu pudar alih-alih menghilang, sehingga dengan diimplementasikannya program Maghrib Mengaji ini dapat menggairahkan kembali masyarakat Bandung yang santun dan religius.

Kedua, berkenaan dengan teori yang dipakai dalam memahami implementasi kebijakan program Maghrib Mengaji ini, digunakan teori yang disampaikan oleh Agranoff \& McGuire (2003), yang melihat bahwa Pemerintah membutuhkan sebuah manajemen kolaborasi, dimana dalam mengimplementasikan sebuah kebijakan itu dibutuhkan banyak aktor yang terlibat, agar masalah yang dihadapi itu akan lebih mudah untuk diselesaikan, karena sejatinya yang menjadi permasalahan publik itu sangat kompleks, tidak mungkin dapat diselasaikan oleh satu aktor saja yaitu Pemerintah. Ini harus dipahami secara komprehensif bahwa dalam konsep implementasi kebijakan berbasis "policy network" 
tersebut, telah menekankan pada sebuah ide logika sederhana dari jaringan dan dampaknya pada kehidupan masyarakat, yaitu filosofi "dari masyarakat, oleh masyarakat, dan untuk masyarakat." Penulis mencoba untuk mengilustrasikannya kedalam contoh program Maghrib Mengaji ini, yaitu karena yang menjadi sasaran utama Maghrib Mengaji ini adalah sekelompok masyarakat Kota Bandung itu sendiri yang masih berusia anak-anak berkisar 514 tahun, maka kelompok masyarakat lainnya yang memiliki kemampuan dan keahlian tertentu sudah seharusnya bisa memberikan kontribusi mereka untuk ikut andil dalam menyukseskan program tersebut, terlebih mereka ini memiliki mobilitas yang cukup tinggi, lebih fleksibel, dapat menyocokkan diri, dan dapat menjadi titik pusat. Namun ini tidak bisa dilakukan dengan sendirinya, melainkan harus ada pihak yang mengkoordinir dan mengorganisirnya, inilah tugas yang harus dilakukan oleh pemerintah dalam rangka memberdayakan masyarakatnya tersebut sehingga kemudian akan lahir sebuah sinergitas, konektivitas, dan harmonisasi hak dan kewajiban di antara kedua belah pihak yang terkait.

Selanjutnya digunakan juga teori yang dikemukakan oleh Honig (2006) bahwa terdapat tiga model dimensi untuk riset implementasi kebijakan, yaitu People, Policy, dan Places. Berkenaan dengan teori ini, dibahas mengenai bagaimana fungsi Pemerintah beserta network-network nya itu mengimplementasikan program Maghrib Mengaji ini. Terlebih dahulu perlu diawali dengan adanya maksud dan tujuan dari Policy itu sendiri, yaitu dalam jangka pendek dapat menjadikan anak-anak Kota Bandung cerdas dalam mengisi waktunya untuk hal yang jauh lebih bermanfaaf yang mengandung nilai ibadah, sehingga dapat dikurangi aktivitas-aktivitas yang tidak jelas selepas Maghrib, sedangkan dalam jangka panjangnya untuk membangun generasi muda Kota Bandung menjadi Generasi Agamis, yang dapat mempersiapkan pemimpin Indonesia Masa Depan yang memiliki karakter akhlakulkarimah, serta cerdas intelektual, sosial dan spiritualnya.

Setelah mengetahui maksud dan tujuan dari Policy tersebut, berlanjut kepada dimensi berikutnya, yaitu People yang terdiri dari beberapa aktor yang terlibat sebagai implementator kunci, seperti pertama Wali Kota Bandung sebagai representasi Pemerintah Kota Bandung, yang bertanggung jawab penuh dalam mengawal pelaksanaan program Maghrib Mengaji ini, Kementerian Agama Kota Bandung sebagai instansi keagamaan yang memberikan panduan (guidance) dalam menjabarkan program Maghrib Mangaji ini menjadi lebih detail. Selanjutnya aktor-aktor kunci kedua yaitu perwakilan kelompok grup atau komunitas, yang telah direpresentasikan oleh Dewan Masjid Indonesia (DMI) Kota Bandung, Muhammadiyah, Persatuan Islam (Persis), dan Nahdlatul Ulama sebagai Ormas Islam terbesar di Kota Bandung, dan Majelis Ulama Indonesia (MUI) Kota Bandung, dimana ketiga wakil ormas/LSM ini berfungsi untuk memobilisasi massa di lapangan dan mengarahkan teknisnya secara langsung. Kemudian aktor yang ketiga berasal dari tim pelaksana lapangan, dimana setiap setelah Maghrib merekalah yang menjadi relawan untuk mengajari baca tulis Iqra dan Al-Qur'an, serta mampu memberikan ceramah keagamaan dan pendidikan karakter kepada anak didik.

Ketiga, dikaitkan sekaligus juga dianalisis tentang penjelasan bagaimana Pemerintah Kota Bandung yang dianggap sebagai network manager ini mampu menjaga serta memelihara komitmen bersama diantara aktor-aktor yang terlibat, yang dihubungkan dengan teorinya (Nakamura 1987), dimana pemerintah mampu memfasilitasi kebutuhan dan mempertimbangkan nilai yang dianut oleh para implementatornya, karena itu adaptasi dan diskresi dalam implementasi seharusnya dilihat sebagai suatu yang dibutuhkan. Terdapat tiga poin penting, yang kiranya perlu mendapat penjelasan lebih jauh terkait memfasilitasi kebutuhan aktor network tersebut, yaitu a) memfasilitasi kebutuhan, yang mana ini telah dirinci oleh teorinya (Gray 1985) bahwa nampaknya pemerintah perlu mempertimbangkan 
kelayakan sisi finansial. Kendati menjadi hal yang paling diperdebatkan, namun hal ini adalah bentuk apresiasi terhadap kinerja yang telah dicapai oleh aktor-aktor tersebut. Poin ini menjelaskan bahwa tim pelaksana lapangan dimungkinkan kedepannya akan mendapat insentif dari Pemerintah Kota Bandung sebagai bentuk penghargaan dari apa yang telah mereka kerjakan, dengan catatan bahwa insentif tersebut diberikan dengan basis kinerja yang jelas dan optimal, Sehingga kedepannya mereka termotivasi untuk lebih mampu lagi meningkatkan kualitas kinerjanya, b) pemerintah perlu meningkatkan kualifikasi keilmuan aktor-aktor ini, disebabkan ilmu pengetahuan yang berkembang ditambah dengan kemajuan teknologi yang semakin canggih. (Agranoff, 2007). Pada poin ini dimaksudkan bahwa ada kemungkinan Pemerintah Kota Bandung kedepannya akan memberikan pelatihan dan pendidikan informal kepada para aktor lapangan ini, dengan tujuan mereka mampu menggabungkan materi keilmuannya dengan penguasaan teknologi, seperti penggunaa slide serta aplikasi lainnya, dan juga dapat mendorong mereka untuk lebih kreatif dan inovatif lagi dalam menyampaikan isi materi kepada anak didik, c) pada poin ketiga ini berdasarkan pada pandangan (Peters, 2000) bahwa Pemerintah perlu menyadari, sebetulnya jaringanjaringannya itu adalah bagian dari "keluarga barunya", sehingga harus tercipta nuansa harmonisasi diantara mereka yang terlibat itu. Seperti misalnya suatu saat Pemerintah Kota Bandung mengundang aktor-aktor network ini untuk menghadiri silaturahmi di Balai Kota dalam rangka menguatkan sisi emosional mereka.

Dan yang terakhir pada poin Keempat, dikaitkan dengan teorinya (Moore 1995) tentang added values for pubic dengan network model nya Agranoff \& Yildiz (2007), yaitu dengan menganalisis bagaimana aktivitas aktor-aktor jejaring tersebut dengan sendirinya akan menambah nilai (value) bagi mereka dan masyarakat secara lebih luas. Poin pertama, dengan berlangsungnya pelaksanaan program Maghrib Mengaji Kota Bandung ini, menjadi momentum tersendiri bagi aktor-aktor jejaring untuk bisa belajar kembali. Meskipun mereka bertugas untuk memberikan ilmu dan kemampuannya kepada anak didik, tetapi akan secara otomatis mereka pun akan terus termotivasi untuk mengembangkan ilmu pengetahuan dan kemampuannya secara autodidak. Poin Kedua, dalam mensukseskan program Maghrib Mengaji ini, aktor-aktor jejaring yang secara individu maupun organisasinya berbeda, akan "dipaksakan" untuk mencair menjadi satu kesatuan dalam melakukan kerjasama, sehingga permasalahan yang begitu kompleks di masyarakat akan lebih mudah untuk diselesaikan, akibatnya pada poin ketiga, yaitu mereka secara alamiah akan memiliki "kemampuan baru", bagaimana mereka mampu mengelola hubungan kerjasama tersebut pada sebuah area yang sebelumnya mereka tidak terbiasa untuk melakukannya yaitu dibawah tugas Pemerintahan Kota Bandung. Poin keempat ialah para aktor network ini akan mendapatkan manfaat yang besar kedepannya, karena dengan sendirinya mereka telah linked satu sama lain dan memiliki akses yang sama untuk bisa masuk ke setiap organisasi atau lembaga yang ada, sehingga kedepannya memungkinkan mereka untuk bisa saling berkomunikasi secara intens. Terakhir pada Poin kelima, yang menurut hemat penulis menjadi poin penting yaitu para suksesor program Maghrib Mengaji ini dengan tanpa disadari, mereka akan lebih termotivasi dalam melaksanakan tugasnya untuk melayani publik, karena mereka adalah orang-orang terpilih yang menjadi kepercayaan Pemerintah Kota Bandung sehingga ada ekspektasi besar yang diberikan kepada para implementator ini untuk dapat melakukan hal lain yang lebih positif terhadap publik yang lebih luas, dalam kaitannya dengan konteks Maghrib Mengaji ini, para implementator akan berusaha untuk memberikan yang terbaik dalam mengajari anak-anak Kota Bandung untuk bisa baca tulis Al-Qur'an dan memberikan materi keagamaan dan pendidikan karakter kepada mereka, sehingga cita-cita Pemerintah Kota Bandung melalui program Maghrib Mengaji ini dapat tercapai. 


\section{Simpulan}

Dalam menyimpulkan penelitian ini, terdapat beberapa poin penting yang harus dicatat dalam kaitannya dengan Implementasi kebijakan program Maghrib Mengaji di Kota Bandung. Dalam mengimplementasikan program Maghrib Mengaji ini, Pemerintah Kota Bandung tidak bisa berjalan sendiri, melainkan perlunya keterlibatan banyak aktor masyarakat yang kemudian bisa menjadi the best partnership yang kooperatif dan interaktif, sehingga mereka mampu berjalan bersama dan beriringan untuk tercapainya tujuan bersama yang diharapkan. Pemerintah Kota Bandung harus mampu menciptakan nuansa harmonisasi diantara mereka yang terlibat layaknya seperti "keluarga baru". Kemudian juga pemerintah perlu memperhatikan apa yang menjadi kebutuhan dari para aktor ini untuk meningkatkan kinerjanya, seperti memberikan pelatihan atau pendidikan informal guna memperbaharui kualifikasi keilmuan mereka, dan juga untuk kedepannya bisa dimungkinkan untuk memberikan insentif bagi suksesor ini sebagai bentuk reward yang layak dari pemerintah, namun dengan catatan bahwa itu semua dapat diberikan dengan basis kinerja yang jelas, efektif, dan optimal. Terdapat added values bagi aktor-aktor network ini, yang mana ini akan teralokasikan secara otomatis kepada mereka, jika mereka mampu memanfaatkan momentum tersebut dengan baik. Sedangkan untuk masyarakat yang lebih luas, dengan adanya pelaksanaan program Maghrib Mengaji ini akan membuat mereka menjadi lebih menyadari akan peran dan fungsi pemerintah melalui programnya tersebut. Hal itu dapat tejadi, jika aktor-aktor jejaringnya mampu bekerja secara baik dan optimal sehingga dapat menggairahkan masyarakat untuk ikut terlibat dalam mendukung dan mensukseskan kebijakan Pemerintah Kota Bandung melalui program Maghrib Mengaji ini.

\section{Referensi}

Agranoff, R., McGuire, M., and Silva, C. 2013. Governance, Networks, and Intergovernmental Systems.

Agranoff, R., Yildiz, M. (2007). Decision-Making in Public Management Networks. Goktug Morcol (ed): Handbook of Decision-Making, Marcel Dekker Publications, 319-345.

Birkland, T.A. (2001). An Introduction to the Policy Process: Theories, Concepts and Model of Public Policy Making. Armonk, New York, London: ME Sharpe, Inc.

Castells, M. (1996). The Rise of the Networks Society (The Information Age: Economy, Society, and Culture). Malden, MA: Blackwell Publishers, Inc

Gray, B. (1985). Conditions Facilitating Interorganizational Collaboration. SAGE Journals. https://doi.org/10.1177/001872678503801001

Honig, M.I. (2006). Street-Level Bureaucracy Revisited: Frontline District Central-Office Administrators as Boundary Spanners in Education Policy Implementation. SAGE Journals. https://doi.org/10.3102/01623737028004357

Keban, Y.T. 2008. Enam Dimensi Strategis Administrasi Publik: Konsep, Teori, dan Isu. Yogyakarta: PT. Gaya Media.

Kilduff, M., Tsai, W. (2003). Social Networks and Organizations. Thousand Oaks, CA: SAGE. https://dx.doi.org/10.4135/9781849209915

Kitchenham, B., Chartes, S. (2007). Guideleines for Performing Systematic Literature Reviews in Software Engineering. Keele University and Durham University Joint Report.

Moore, M.H. (1995). Creating Public Value: Strategic Management in Governement. Harvard University Press. 
Nakamura, R.T. (1987). The Textbook Policy Process and Implementation Research. Policy Studies Review, 7 (1), 142-154. https://doi.org/10.1111/i.1541-1338.1987.tb00034.x

Peters, B.G. (2000). Policy Instruments and Public Management: Bridging the Gaps. Journal of Public Administrastion Research and Theory. 10 (1): 35-47. 10.1093/oxfordjournals.jpart.a024265

Santosa, P. 2012. Adminitrasi Publik Teori dan Aplikasi Good Governnace. Bandung: Refika Aditama

Tsang, W.K. 2013. Policy Process Studies: Policy Implementation. PEDU 6209

Warsono, H. 2009. Kolaborasi dan Kerjasama Antardaerah. Yogyakarta: PT. Gaya Media MAP UGM

Kantor Wilayah Kementerian Agama Provinsi Jawa Barat. 2016. Walikota Bandung Launching Program Maghrib Mengaji diakses melalui https://jabar.kemenag.go.id/portal/read/walikota-bandung-launching-programmaghrib-mengaji.

Badan Pusat Statistik Kota Bandung. 2020. Kota Bandung dalam Angka 2020 diakses melalui https://bandungkota.bps.go.id/publication/download.html?nrbvfeve=YTR1Y2M1NW UwZjgyY2U1MGU4NDc1ZjVj\&xzmn=aHR0cHM6Ly9iYW5kdW5na290YS5icHM uZ28uaWQvcHVibGljYXRpb24vMjAyMC8wMi8yOC9hNGVjYzU1ZTBmODJjZT UwZTg0NzVmNWMva290YS1iYW5kdW5nLWRhbGFtLWFuZ2thLTIwMjAtLXB1 bnllZGlhYW4tZGF0YS11bnR1ay1wZXJlbmNhbmFhbi1wZW1iYW5ndW5hbi5odG 1s\&twoadfnoarfeauf=MjAyMC0wNi0yNiAwMzozMDoxNA\%3D\%3D

Hutagaol, S. 2019. Ratusan Anak Masuk RSJ karena Kecanduan Gadget Jadi Tamparan Semua Keluarga diakses melalui https://nasional.okezone.com/read/2019/10/19/337/2119073/ratusan-anak-masuk-rsjkarena-kecanduan-gadget-jadi-tamparan-semua-keluarga. 